\title{
Reactivation of polyomavirus in bone marrow transplant recipients
}

\author{
H A Cotterill, M E Macaulay, V Wong
}

\begin{abstract}
Polyomavirus was detected in the urine samples of $12(48 \%)$ out of 25 patients within three months of receiving a bone marrow transplantation. The virus was first detected 11 to 46 days after the transplantation and excretion persisted for up to $\mathbf{4 2}$ days. Detection of the virus was not associated with symptoms and it seemed to be a marker of immunosupression.
\end{abstract}

Detection of polyomavirus in patients' urine after bone marrow transplantation (BMT) has been described in association with hepatic dysfunction $^{1}$ and haemorrhagic cystitis. ${ }^{2-4}$ O'Reilly et al, using electron microscopy, detected polyomavirus in $\mathbf{1 7}$ out of $\mathbf{4 5}$ patients after BMT. ${ }^{2}$ A review of the patients' clinical course suggested that there was an association between mild hepatic dysfunction and virus excretion. Arthur et al used an enzyme linked immunoabsorbent assay (ELISA) and DNA hybridisation to monitor the presence of $\mathrm{BK}^{23}$ and $\mathrm{JC}^{3}$ virus after $\mathrm{BMT}$. They found $\mathrm{BK}$ virus in about $50 \%$ of patients, in whom it was associated with severe haemorrhagic cystitis. JC virus, less frequently detected $(7 \%)$, was not associated with symptoms. Arthur et al did not find any association between either virus and hepatic dysfunction. ${ }^{3}$ Apperley et al described eight patients with papovavirus after BMT, three of whom had haemorrhagic cystitis. ${ }^{4}$

In this study electron microscopy was used to examine four or more urine samples (mean eight per patient) from 25 patients in the three months following BMT for haematological malignancies. Urine samples were received either neat ( 70 out of 200 ) or diluted in an equal volume of virus transport medium (VTM) and $2 \mathrm{ml}$ aliquots were ultracentrifuged at $65000 \mathrm{~g}$ for one hour at $+8^{\circ} \mathrm{C}$. The resulting pellets were resuspended in distilled water. A pioloform-coated copper grid was floated on a drop of suspension and, after blotting, negative staining was performed using $3 \%$ aqueous phosphotungstic acid at $\mathrm{pH} 6 \cdot 3-6 \cdot 5$.

Polyomavirus was easily detected, being present in large numbers, even when the urine had been diluted in an equal volume of VTM.
The virus was detected by electron microscopy in 34 urine samples from $12(48 \%)$ of the patients and was first seen between 11 and 46 days (mean 29 days) after BMT. Twenty two of the 34 electron microscopy positive urines were received in VTM and these were also cultured in MRC fibroblasts. A cytopathic effect was seen in $15(68 \%)$ specimens after nine to 48 days. The cytopathic effect occurred mainly at the edge of the cell sheet and consisted of isolated, large, round, slightly refractile cells. In the nine patients in whom virus was found in more than one urine sample it persisted for seven to $\mathbf{4 2}$ days. These results are very similar to those of other workers. No association was found between virus excretion and either haemorrhagic cystitis or hepatic dysfunction.

There is a high prevalence of antibodies to human polyomavirus in the general poptulation. ${ }^{56}$ Thus the virus seen in the present study was considered to be due to reactivation. It is difficult to attribute symptoms to any one cause after BMT, as cytotoxic treatment, graft versus host disease, and infection may all lead to morbidity. It may be that this multiple pathology obscured the part played by polyomavirus in our patients' symptoms, but an alternative explanation is that there may have been subtle differences in our patient group or in their treatment that limited the pathogenicity of polyomavirus. In spite of the large amount of virus excreted in the urine, polyomavirus in our patients seemed to be a marker of immunosuppression which did not cause any associated morbidity.

1 O'Reilly RJ, Lee FK, Grossbard E, et al. Papovavirus excretion following marrow transplantation: incidence and association with hepatic dysfunction. Transplant Proc 1981;13:262-6.

2 Arthur RR, Shah KV, Baust SJ, Santos GW, Saral R. Association of BK viruria with haemorrhagic cystitis in recipients of bone marrow transplants. $N$ Engl $J$ Med recipients of bon:315:230-4.

3 Arthur RR, Shah KV, Charache P, Saral R. BK and JC virus infections in recipients of bone marrow transplants. $J$ infections in recipients of

4 Apperley JF, Rice SJ, Bishop JA, et al. Late onset haemorrhagic cystitis associated with urinary excretion of polyomavirus after bone marrow transplantation. Transplantation 1987;43:108-12.

5 Shah KV, Daniel RW, Warzawski RM. High prevalence of antibodies to BK virus, an SV40 related papovavirus in residents of Maryland. J Infect Dis 1973;128:784-7.

6 Gardener SD. Prevalence in England of antibodies to human polyomavirus (BK). Br Med J 1973;1:177-8. 